\title{
DEVELOPING AND EVALUATING PROFESSIONAL COMPETENCES OF STUDENTS SPECIALIZING IN PEDAGOGY
}

\author{
DESENVOLVENDO E AVALIANDO COMPETÊNCIAS PROFISSIONAIS DE ALUNOS \\ ESPECIALIZADOS EM PEDAGOGIA
}

\author{
DESARROLLAR Y EVALUAR LAS COMPETENCIAS PROFESIONALES DE LOS \\ ESTUDIANTES ESPECIALIZADOS EN PEDAGOGÍA
}

\author{
Aigul Raisovna GILMUTDINOVA ${ }^{1}$ \\ Liliya Rafhatovna NIZAMIEVA ${ }^{2}$ \\ Gulnara Ilsurovna NAZAROVA ${ }^{3}$ \\ Elena Rafaelevna PORSHNEVA ${ }^{4}$
}

\begin{abstract}
The article is devoted to the problem of developing professional competences of future teachers of foreign languages during the pedagogical internship while studying at the university. In connection with a constant rise in qualification requirements for the teaching staff of educational institutions of various levels, it is necessary to develop an efficient model of formation for future specialists in the educational field, enabling high-quality formation for the sound solution of modern professional problems. The main professional educational program is focused not only on the quality and volume of acquired knowledge, skills and abilities, but also the level of competency development. All educational disciplines are aimed at developing both general and professional competences; however, it is the pedagogical internship organized during the study at the university that allows evaluating the level of their development in the context of professional activity, to identify possible gaps in professional and pedagogical knowledge, skills and abilities, and to find ways to overcome them. The aim of the research is to develop an efficient model for building professional competences of future specialists in the field of teaching foreign languages during pedagogical internship. The study revealed that such a model should include determining the objectives of internship, developing its work program, containing all the necessary information about the internship, holding an introductory conference with students, a detailed analysis of all the points of an intern's individual assignment, explaining the requirements for reporting documentation, methodological support and controlling students during the internship, stocktaking exercise with a clear assessment procedure. The key indicator of the success of pedagogical internship is the level of development of professional competences of future specialists.
\end{abstract}

\footnotetext{
${ }^{1}$ Kazan Federal University (KPFU), Kazan - Russia. Associate Professor of the Department of Theory and Practice of Teaching Foreign Languages, Institute of Philology and Intercultural Communication. PhD in Philology. ORCID: https://orcid.org/0000-0002-5670-8302.E-mail: kaigel@mail.ru

${ }^{2}$ Kazan Federal University (KPFU), Kazan - Russia. Associate Professor of the Department of Theory and Practice of Teaching Foreign Languages, Institute of Philology and Intercultural Communication. Candidate of Pedagogy. ORCID: https://orcid.org/0000-0002-0913-8589. E-mail: lilianiz@yandex.ru

${ }^{3}$ Kazan Federal University (KPFU), Kazan - Russia. Associate Professor of the Department of Theory and Practice of Teaching Foreign Languages, Institute of Philology and Intercultural Communication. Candidate of Pedagogy. ORCID: https://orcid.org/0000-0001-7625-4291.E-mail: gulnazar@yandex.ru

4 Nizhny Novgorod State Linguistic University (LUNN), Nizhny Novgorod - Russia. Professor of the Department of Theory and Practice of the French Language and Translation, Faculty of Translation. Doctor of Pedagogy. ORCID: https://orcid.org/0000-0002-5940-0442. E-mail: erp@lunn.ru
} 
KEYWORDS: Foreign languages. Teaching methods. Professional competences. Pedagogical internship. Organizational and methodological support of the educational process.

RESUMO: $O$ artigo é dedicado ao problema do desenvolvimento de competências profissionais de futuros professores de línguas estrangeiras durante o estágio pedagógico enquanto se estuda na universidade. Em conexão com um constante aumento das exigências de qualificação para o pessoal docente de instituições educacionais de vários níveis, é necessário desenvolver um modelo eficiente para a formação de futuros especialistas na área educacional, permitindo uma capacitação de alta qualidade como uma real solução para os problemas profissionais modernos. O principal programa educacional profissional está focado não apenas na qualidade e volume de conhecimentos, capacidades e habilidades adquiridas, mas também no nível de desenvolvimento de competências. Todas as disciplinas educacionais têm como objetivo desenvolver tanto as competências gerais quanto as profissionais; entretanto, é o estágio pedagógico, organizado durante o estudo na universidade, permite avaliar o nível de seu desenvolvimento no contexto da atividade profissional, para identificar possíveis lacunas nos conhecimentos, competências e habilidades profissionais e pedagógicas, para identificar formas de superá-las. O objetivo da pesquisa é desenvolver um modelo eficiente para a construção de competências profissionais de futuros especialistas na área do ensino de línguas estrangeiras durante o estágio pedagógico. O estudo revelou que tal modelo deve incluir a determinação dos objetivos do estágio, o desenvolvimento de seu programa de trabalho contendo todas as informações necessárias sobre o estágio, a realização de uma conferência introdutória com os estudantes, uma análise detalhada de todos os pontos do trabalho individual de um estagiário, explicando os requisitos para a apresentação de documentação, apoio metodológico e controle dos estudantes durante o estágio, exercício de balanço com um procedimento de avaliação claro. $O$ indicador-chave do sucesso do estágio pedagógico é o nível de desenvolvimento das competências profissionais dos futuros especialistas.

PALAVRAS-CHAVE: Línguas estrangeiras. Métodos de ensino. Competências profissionais. Estágio pedagógico. Suporte organizacional e metodológico do processo educacional.

RESUMEN: El artículo está dedicado al problema del desarrollo de las competencias profesionales de los futuros profesores de lenguas extranjeras durante la pasantía pedagógica mientras estudian en la universidad. En conexión con un aumento constante de los requisitos de calificación para el personal docente de las instituciones educativas de varios niveles, es necesario desarrollar un modelo eficiente para la formación de futuros especialistas en el campo educativo, que permita una formación de alta calidad para la solución sólida de los problemas profesionales modernos. El principal programa educativo profesional se centra no solo en la calidad y el volumen de los conocimientos, habilidades y habilidades adquiridos, sino también en el nivel de desarrollo de competencias. Todas las disciplinas educativas están orientadas al desarrollo de competencias tanto generales como profesionales; sin embargo, es la pasantía pedagógica organizada durante el estudio en la universidad la que permite evaluar el nivel de su desarrollo en el contexto de la actividad profesional, identificar posibles brechas en los conocimientos, destrezas y habilidades profesionales y pedagógicas, identificar formas de superarlas. El objetivo de la investigación es desarrollar un modelo eficiente para la construcción de competencias profesionales de futuros especialistas en el campo de la enseñanza de lenguas extranjeras durante las

RPGE- Revista on line de Política e Gestão Educacional, Araraquara, v. 25, n. esp. 1, p. 419-427, mar. 2021. 
prácticas pedagógicas. El estudio reveló que dicho modelo debería incluir la determinación de los objetivos de la pasantía el desarrollo de su programa de trabajo que contenga toda la información necesaria sobre la pasantía, la celebración de una conferencia introductoria con los estudiantes, un análisis detallado de todos los puntos de la tarea individual de un pasante, explicando el requisitos de documentación, soporte metodológico y control de los estudiantes durante la pasantía, ejercicio de balance con un procedimiento de evaluación claro. El indicador clave del éxito de las prácticas pedagógicas es el nivel de desarrollo de las competencias profesionales de los futuros especialistas.

PALABRAS CLAVE: Idiomas extranjeros. Métodos de enseñanza. Competencias profesionales. Prácticas pedagógicas. Apoyo organizativo y metodológico del proceso educativo.

\section{Introduction}

Developing professional competence of future specialists in the field of teaching foreign languages should be aimed at ensuring a high level of preparation of graduates for the organization and implementation of the educational process in the current context. The introduction of new state educational standards resulted in changes in understanding the aims and objectives of teaching university students (http://fgosvo.ru/fgosvo/92/91/4). The ultimate objectives of mastering the basic professional educational program are not only the quality and volume of acquired knowledge, skills and abilities, but also the level of proficiency in professional competences (GAFIYATOVA; GAYNUTDINOVA; GALIAKHMETOVA, 2019). A competence is not just a sum of knowledge, skills and abilities, but also the ability and readiness to use them in practice.

On the basis of the competency building approach, a graduate should have a certain amount of competences, which are divided into groups: common cultural, general professional, professional ones (ABDRAFIKOVA; KONOPATSKAYA, 2014). Mentioning the evidence of the development of competences, it should be noted that the results of activities, namely internship, make it possible to assess them. The development strategy of Russian education implies the need for arranging various forms of pedagogical internship in pedagogical universities, which most fully contributes to the professional development of students (KUZNETSOVA; KUZNETSOV; ZAMALETDINOV, 2016).

The aim of pedagogical internship is to develop the professional competence of future teachers in the process of solving educational and professional problems, including while working in educational institutions. Pedagogical internship is a means of mastering not only professional skills, but also modern teaching methods and pedagogical experience. It 
contributes to the development of pedagogical thinking and provides opportunities for the application of theoretical knowledge in practical activity.

Thus, pedagogical internship is an integral part of developing professional competence of a student - a future teacher. At the same time, there are many difficulties in the process of organizing internship, which can be overcome by sound planning and determination of the stages of professional training of future specialists. This can be done when developing programs of various kinds of internship within existing educational programs for certain pedagogical specialties.

\section{Methods}

The aim of the study is the development of an efficient model for developing professional competences of future specialists in the field of teaching foreign languages during pedagogical internship.

The main research methods include the analysis of specification documents, namely, the basic vocational educational program and the work program of pedagogical internship in the undergraduate program "Pedagogical Education" (4 years of study), the profile "Foreign (French) language', as well as modeling, and focused pedagogical observation.

In the structure of the analyzed basic professional educational program, pedagogical internship is carried out both in the 3rd year of study in the 5th semester and in the 4th year of study in the 7th semester. The total volume of internship is 12 credits.

One of the main stages of arranging pedagogical internship is the development of a program for its implementation. Mandatory elements of the work program of internship are the type of internship, the way and form of its implementation, the list of expected results of the study during the internship, related to the expected results of mastering the educational program, the place of internship in the structure of the educational program, the volume and content of the internship, reporting forms and assessment means for intermediate certification of interns.

Thus, the type of the internship we are considering is a traineeship; it is pedagogical internship in the profile of training. As for the ways of its implementation, internship may be stationary or field. In its form, this internship qualifies as off-studies internship, i.e. for its implementation a continuous period of academic time, free from other types of educational activities, is allocated in the academic calendar. 
The program of internship must necessarily contain the main goals of its organization, stated as the expected results of implementing this type of activity.

The expected results of study during internship are competences that a graduate who has mastered the program of internship should have, the results correlate with the general goals of mastering the whole educational program.

As a result of mastering internship program, the student should demonstrate skills in modern technologies in French language teaching in a secondary school (MAMAEVA et al., 2017), ways and methods of developing students' communicative competence in a foreign language (SHEMSHURENKO et al., 2019). methodology for teaching oral and written speech, means and techniques of knowledge assessment, the ability to plan the educational process and extracurricular activities in the French language, to carry out educational activities.

\section{Results and discussion}

Preliminary preparation for arranging pedagogical internship includes concluding contracts governing the organization and conducting of internship. Similar contracts are concluded with educational institutions, secondary schools, which act as executing agencies and make commitments to organize and conduct internship for university students. Except providing places for internship, executing agencies also undertake to select qualified specialists from the staff to guide the internship of students, to create necessary conditions for students to develop professional competences in the field of training.

For its part, the university appoints heads of internship, whose duties include acquainting students with the program of internship. This is done during an introductory conference for students-interns. The conference is organized a few days before the start of the internship and includes such important aspects as distribution of students among educational institutions, safety induction training, a description of goals, objectives, content and methods of organizing pedagogical internship, the characteristics of reporting documents which should be provided at the end of study. During the conference, a detailed analysis of all points of a trainee's individual assignment is carried out, specifying the precise content and expected results, as well as the dates for the implementation.

The individual task of students' pedagogical internship includes attending the lessons of a French teacher during the first week of the allocated period, as well as developing detailed plans of their own French lessons. During the rest of the internship, it is planned to 
hold French lessons, some of which are monitoring ones and are subject to evaluation by the head of internship. Trainees should also attend classes of other students-interns at the same educational institution and take part in the analysis and discussion of the lessons.

In order to build skills and competences of educational work, trainees should develop a scenario for an educational event and organize it during the internship period.

The last item of the individual assignment is processing reporting documents, which a trainee must provide to a university head of internship at the end of pedagogical internship. A student's report on completed internship should include a description of the organization of work and the achieved results in sections of the program, with the indication of practical tasks to be solved during the internship, a description of the implementation of all points of an individual task. In the final part of the report it is recommended to provide a description of competences developed by a trainee during the internship, suggestions and recommendations of a student made during the internship.

A character reference reflecting the quality of an intern's training and work during the period of internship given by the administration of the educational institution is attached to the report. It characterizes professional skills acquired by a student, his attitude to work, workplace discipline.

At the end of the pedagogical internship, a final conference is held at which the results of the internship are analyzed and summarized, a general characteristics of the work of interns in various educational institutions is provided, accomplishments and shortcomings in preparing and organizing internship are identified, and the grades got by students are announced.

Certification on the basis of the results of the internship includes a public presentation of its results based on the submitted report followed by evaluation. Evaluating the results of internship includes evaluating the level of demonstrated knowledge in the field of educational psychology and methods of teaching the French language, the ability to create a positive emotional climate in the classroom, to arouse and maintain an interest in the subject, to make contact with students, the level of an intern's language skills (CLERC; MARTIN, 2011). The head of internship evaluates the volume and implementation dates of the internship program and individual tasks of interns. The key indicator of the success of the internship is the level of development of professional competences of the future teacher, demonstrated by students. 


\section{Summary}

Pedagogical internship is aimed at forming the student's readiness for independent creative learner-centered pedagogical activity. In general, the procedure of evaluating knowledge, abilities, skills and practical experience implies determining the degree of achievement of basic tasks assigned to interns, among which the most important ones are:

- Developing individual pedagogical competence;

- Development of pedagogical abilities, pedagogical position, professional skills;

- Mastery of modern learner-centered pedagogical technologies of developing foreign language communicative competence;

- Mastery of humanitarian grounds of education and development of a child's personality;

- Development of personal qualities significant for a specialist, a desire for self-education and self-improvement as man of world culture;

- Understanding of the substance and content of the process of university education as the fundamental basis of learner-centered pedagogical activity, its creative improvement (ANTONOVA; VASSILIEVA; KONONENKO, 2016).

On the basis of the conducted analytical work, pedagogical observation and our own experience in organizing pedagogical internship, a model for developing professional competences of future specialists has been developed. The model of organizing pedagogical internship allows students to acquire necessary professional experience and demonstrate key results of training at a pedagogical university, which are evaluated via professional competences that an intern is ready to implement as a foreign language teacher.

A student who has served an internship should be able to provide training, education and development of schoolchildren, taking into account social, age, psychophysical and individual characteristics, including specific educational needs of students. He should be able to organize students' cooperation, maintain their activity, initiative and independence, develop their creative abilities. Furthermore, a future specialist should have the ability to independently acquire new knowledge and skills, including with the help of information technology, and apply them to actual activity, as well as creatively adopt innovative techniques and technologies in professional teaching activities (ANTONOVA; VASSILIEVA; KONONENKO, 2016). 


\section{Conclusions}

Improving the competitiveness of future specialists in the global labor market implies the focus of arranging educational activities at the university on the efficient development of professional competences of graduates (SCHANTZ, 2012). The acquisition of the competences by students of pedagogical universities requires students' understanding of social significance of their future profession, the ability to use systematic theoretical and practical knowledge, acquired skills and abilities for defining and solving both practical and research problems in the field of education.

Developing professional competences of a future teacher is impossible without a purposeful and systematic organization of pedagogical internship during study at a university. The efficiency of pedagogical internship directly depends on its careful management. Creating efficient models for developing professional competences of specialists in the field of teaching foreign languages requires a clear definition of requirements for the organization of pedagogical internship, including defining the goals of internship, its expected results, the development of a work program, and holding introductory and final conferences. During the internship, it is vital to provide continuous methodological support and control of students compliant with the established assessment procedure. The compliance with aforementioned requirements for organizing pedagogical internship promotes efficient development and implementation of professional competences of future specialists.

ACKNOWLEDGEMENTS: The work is performed according to the Russian Government Program of Competitive Growth of Kazan Federal University.

\section{REFERENCES}

ABDRAFIKOVA, A. R.; KONOPATSKAYA, E. A. The case study technologies as the means of competency building approach realization in higher education of Russia. English Language Teaching, v. 7, n. 12, p. 94-99, 2014.

ANTONOVA, N. V.; VASSILIEVA, V. N.; KONONENKO, M. V. The problem of quality of education in foreign language teaching. Journal of Language and Literature, v. 7, n. 2, p. 159-162, 2016.

CLERC, A.; MARTIN, D. L'étude collective d'une leçon, une démarche de formation pour développer et évaluer la construction des compétences professionnelles des futurs enseignants. Revue internationale de pédagogie de l'enseignement supérieur, v. 27, n. 2, p. 1-16, 2011. DOI: https://doi.org/10.4000/ripes.514

RPGE- Revista on line de Política e Gestão Educacional, Araraquara, v. 25, n. esp. 1, p. 419-427, mar. $2021 . \quad$ e-ISSN:1519-9029 
RUSSIA. Federal State Educational Standard for Higher Education in Bachelor Program. 2012. Available: http://fgosvo.ru/fgosvo/92/91/4. Access: 10 dec. 2020.

GAFIYATOVA, E. V.; GAYNUTDINOVA, D. Z.; GALIAKHMETOVA, A. T. The integration of pedagogical technologies as a condition for improving the quality of education. 3C TIC, p.127-139, 2019.

KUZMINA, E. K.; NAZAROVA, G. I.; NIZAMIEVA, L. R.; LEBLANC, C. The interactive and independent work of students in their training in French language on the basis of "flipped classroom" technology. Dilemas Contemporáneos: Educación, Política y Valores, v. 6, 2018.

KUZNETSOVA, T. I.; KUZNETSOV, I. A.; ZAMALETDINOV, R. R. Developing and improving professional skills and personality traits as indicators of foreign language teachers ability for applying personal approach to the teaching of students. The European

Proceedings of Social \& Behavioural Sciences, p. 335-340, 2016. DOI:

http://dx.doi.org/10.15405/epsbs.2016.07.53

MAMAEVA, A. D.; VASSILIEVA, V. N.; NAZAROVA, G. I.; GALEEVA, G. I.; LEBLANC, C. The experimental research of "techno-r" technology in teaching the aspect of speaking a foreign language as a type of vocal activity. Revista Publicando, v. 4, n. 13, p. 517-525, 2017.

SCHANTZ, E. A. Professional training of university students as a holistic educational system. Theory and practice of education in the modern world, v. 1, p. 383-386, 2012.

SHEMSHURENKO, O. V.; NIZAMIEVA, L. R.; NAZAROVA, G. I.; BROUSSOIS, G. "Creating an effective form of communication strategy in foreign language learning.

Universal Journal of Educational Research, v.7, n 10 B, p.1-4, 2019.

\section{How to reference this article}

GILMUTDINOVA, A. R.; NIZAMIEVA, L. R.; NAZAROVA, G. I.; PORSHNEVA, E. R. Developing and evaluating professional competences of students specializing in pedagogy. Revista on line de Política e Gestão Educacional, Araraquara, v. 25, n. esp. 1, p. 419-427, mar. 2021. e-ISSN:1519-9029. DOI: https://doi.org/10.22633/rpge.v25iesp.1.14978

Submitted: $06 / 11 / 2020$

Required revisions: 18/01/2021

Approved: $23 / 02 / 221$

Published: 01/03/2021 